\title{
IPO pricing: Do institutional and retail investor sentiments differ?
}

\section{Introduction}

A high first day initial public offering (IPO) return is a global and persistent phenomenon (Ritter, 1984). On average, the first day closing price of an IPO share is well above its issue price. For instance, Ljungqvist and Wilhelm (2002) document an average first day IPO return in France, Germany, and UK are $16.5 \%, 40.2 \%$, and $39.6 \%$, respectively. Besides the popular asymmetric information-based explanation ${ }^{1}$, Derrien (2005), Cook et al. (2006), and Ljungqvist et al. (2006) show that investor sentiment explains the high first day IPO return.

The IPO literature assumes investors are homogeneous, however. That is, these homogenous investors face information asymmetry or have the same sentiment in the IPO process. There is no distinction between retail versus institutional investors. In reality, investors are heterogeneous. Previous studies suggest that institutional investors have more resource and are better informed than retail investors (e.g., Park et al., 2014). It is natural that institutional investors have different sentiments from retail investors about the prospect of the IPO firm in the future. The challenge is to separate the impacts of institutional from retail investors in the IPO pricing process.

We leverage a recent regulatory change in China that mandates the disclosure of institutional investor bidding information in the IPO book-building to separate the sentiments of institution and retail investors. Institutional investors submit their bids in an offline stage after an underwriter proposed a price range. Armed with the book-building information, the underwriter set the IPO issue price. Then, retail investors submit their bids in the online stage.

\footnotetext{
1 See, for example, Beatty (1989).
} 
The mandatory disclosure of institutional bidding information in China provides a unique opportunity to conduct our examination. Specifically, prior studies examine first-day and long-term IPO return from the viewpoint of retail investor sentiment by the demand quantity (e.g., Derrien, 2005) or the amount of retail investor attention (e.g., Cook et al., 2006). The "investor" does not specifically refer to institutional or retail investors. It is not clear if the impact of institutional and retail investors are the same.

With the detailed institution bid data, we use the bid price dispersion and over-subscription ratio to capture their sentiment. For retail investors, the IPO price is predetermined. Hence, we use retail investors' over-subscription ratio to proxy their sentiment. Hence, we can separate their respective sentiments to account for their separate impacts on IPO pricings. Our study represents a first study on the different impacts of institutional and retail investor sentiment on first day and long-term IPO return.

We make two contributions to the literature. First, by separating the impact of institutional and retail investor sentiments, we show that both sentiments explain first day IPO return. Hence, our paper compliments the investor sentiment IPO literature (e.g., Ljungqvist et al., 2006). Second, our long-term IPO return results suggest that only retail investor sentiment matters; suggesting that it is useful to separate the impacts of institutional and retail investor in IPO long-term studies.

\section{Data, key variable definitions, and research method}

\subsection{Data}

Our sample covers from November 1, 2010, to December 31, 2012. We begin on November 1, 2010 because it was the date in which the mandatory disclosure occurred. We 
stop on December 31, 2012, because we need to calculate 3-year long-term IPO performance using three years of post-IPO stock returns. We have a total of 479 IPOs during the period. The pre- and post-IPO financial information is obtained from the China Stock Market \& Accounting Research database (CSMAR). We winsorize the data at $1 \%$ and $99 \%$ level.

\subsection{Key variable definitions}

We follow the literature to capture the first day IPO return (FDRET) as:

$$
F D R E T=(C L O S E-I S S U E) / I S S U E-M A R K E T
$$

where CLOSE is the first day closing price of the IPO shares, ISSUE is the IPO issuing price, and MARKET is the market value weighted return on the same day. For the 3-year long-term IPO return (LONGRET3), we follow Purnanandam and Swaminathan (2004) to regress each IPO's weekly excess return (stock return minus risk-free rate) starting the first week after it went public and ending three years after using Fama and French three factors for the same period. LONGRET3 is the intercept of the regression equation multiplied by 156 . To get robust results, we use a similar methodology to obtain a 2-year long-term IPO return (LONGRET2).

We capture institutional investor sentiment by two measures. First, it is their over-subscription ratio (INST_OVER). Second, it is their views on IPO price (INST_PSENT) using Equation (2) below:

$$
\text { INST_PSENT }=(E Q U I L-M E A N) / M E A N
$$

Where EQUIL is the equilibrium bidding price of institutional investors, which is the bidding price that the bidding share quantities equal to the IPO issuing share quantities; MEAN is the 
mean bidding price of institutional investors. ${ }^{2}$ It captures directly price-related investor sentiment, which is what really matters in theoretical investor sentiment models such as those in Derrien (2005). To account for the institutional investor bidding price (INST_BID) effect on FDRET, we use (MEAN - MIDPOINT) / MIDPOINT; where MIDPOINT is the midpoint of the proposed price range of the IPO. INST_BID is a control variable. The retail investor sentiment is measured by the online oversubscription rate (RETAIL_OVER).

\subsection{Research Methods}

To examine our research question, we use the following multiple regression model:

$$
\text { FDRET }_{i, t}=\alpha_{0}+\alpha_{1} I N S T_{-} P S E N T_{i, t}+\alpha_{2} I N S T_{-} O V E R_{i, t}+\sum \alpha_{j} \text { Control }+ \text { Year }+
$$

Industry+ei,t

The control variables in Equation (3) fall into two categories. The first category relates to the IPO process including: institutional investors' mean bid price (INST_BID), logarithm of the total number of institutional investor bids (LNNUM), proposed IPO price range (RANGE), logarithm of the average online oversubscription ratios of the 10 most recent IPOs (LNLAG10), IPO activities in the same industry of the IPO firm (INDACT), underwriter reputation (REPU), lock-up requirement reform (REFORM), and a dummy variable to indicate if the IPO firm is listed in the man board (MAIN). The second category accounts for the IPO firm characteristics one-year prior to IPO including: return on assets $(R O A)$, leverage ratio of the IPO firm (LEV), total revenue in

\footnotetext{
${ }^{2}$ Since IPOs in China are highly oversubscribed, the equilibrium bidding price is higher than average bidding price. The equilibrium-average price divergence thus measures the sentiment of optimistic institutional investors. Substituting the equilibrium price with the highest bidding price of institutional investors does not affect our findings.
} 
logarithm (LNREV), and fixed asset ratio (FIXRAT).

The IPO sentiment literature (e.g., Derrien, 2005 and Cook et al., 2006) suggests that retail investor sentiment explains first day IPO return. Hence, we expect $\alpha_{3}$ is positive and significant in Equation (3). However, for institutional investor sentiment, it is not clear. Therefore, the signs and significance of $\alpha_{1}$ and $\alpha_{2}$ are uncertain. To examine the impact of institutional and retail investor sentiment on long-term IPO return, we use LONGRET3 to replace FDRET in Equation (3) and control for industry and year effects.

\section{Results and discussions}

We present the results for the impact of institutional and retail investor sentiments on first day IPO return in columns (1) to (3) of Table 1. The reduced model in column (1) show that, consistent with the sentiment literature, the coefficient of RETAIL_OVER is positive and significant at the $1 \%$ level; suggesting retail investor sentiment is positively correlated with the first day IPO return. For the reduced model of institutional sentiment in column (2), the coefficients of INST_PSENT, and INST_OVER are positive and significant at the $1 \%$ and $10 \%$ levels. For the full model in column (3), the results are qualitatively similar to those in columns (1) and (2). That is, both institutional and retail investor sentiments explain the first day IPO return in China. Our findings complement those in the IPO literature on the positive correlation between investor sentiment and first day IPO return. We clarify that, not just the retail investor sentiment, it is indeed all investor sentiment relate to first day IPO return.

We present the impact of institutional and retail investor sentiment on long-term IPO return in Table 2. For brevity, we only present the coefficients of the sentiment variables. Following the literature, we focus on the 3-year post-IPO return in column (1). For robustness, 
we also include 2-year post-IPO return in column (2). The coefficients of RETAIL_OVER are negative and significant at the $5 \%$ level in both columns; suggesting the long-term IPO returns are negatively correlated with retail investor sentiment. In contrast, none of the coefficients of institutional investor sentiment variables (INST_PSENT and INST_OVER) are significant. Hence, the reported poor long-term IPO performance is primarily due to the retail investor sentiment, not the institutional investor sentiment. The finding is consistent with the notion that institutional investors have more resources and their sentiment rightfully reflects the long-term intrinsic value of the IPO firm. Thus, institutional investors (as a group) do not overvalue the IPO shares in the long-term and hence, the long-term IPO return is not related to their sentiment. Conversely, retail investors do not have a lot of resources to do the correct assessment on the long-term value of the IPO shares. These retail investor sentiment, once positive in the short-term, continues to carry over to the long-term. Hence, they have long-term overvaluation and hence, the long-term IPO negative return is negatively related to their sentiment.

\section{Summary}

Using a unique mandatory disclosure of institutional investor bidding information in the Chinese IPO, we are able to identify the institutional and retail investor sentiments. We report that the sentiments from both groups of investors positively contribute to the first day IPO return. The negative long-term IPO return, however, is negatively correlated with only retail investor sentiment; suggesting the impact of institutional investor sentiment is different from that of retail investor. It is useful to distinguish them in IPO pricing. 


\section{References}

Beatty, R., 1989. Auditor reputation and the pricing of IPOs, Accounting Review, 64, 693-709.

Cook, D.O., R. Kieschnick, and R.A. Van Ness, 2006. On the marketing of IPOs, Journal of Financial Economics, 82, 35-61.

Derrien, F., 2006. IPO pricing in "hot" market conditions: Who leaves money on the table? Journal of Finance, 60, 487-521.

Ljungqvist, A., V. Nanda, and R. Singh, 2006. Hot markets, investment sentiment, and IPO pricing, Journal of Business, 79, 1667-1702.

Ljungqvist, A. and W.J. Wilhelm, Jr., 2002. IPO allocations: discriminatory or discretionary, Journal of Financial Economics, 65, 167-201.

Park, T. J., Y. Lee, and K. R. Song, 2014. Informed trading before positive vs. negative earnings surprises, Journal of Banking and Finance, 49, 228-241.

Purnanandam, A.K. and B. Swaminathan, 2004. Are IPOs really underpriced? Review of Financial Studies, $17,811-848$.

Ritter, J., 1984. Signaling and the valuations of unseasoned new issues: A comment, Journal of Finance, 39, 1231-1237. 
Table 1. Institutional and retail investor sentiment and IPO first day return

\begin{tabular}{|c|c|c|c|}
\hline & \multicolumn{3}{|c|}{ Dependent variable $=F D R E T$} \\
\hline & (1) & $(2)$ & (3) \\
\hline INTERCEPT & $\begin{array}{l}-0.6597^{*} \\
(-1.72)\end{array}$ & $\begin{array}{l}0.2672 \\
(0.64)\end{array}$ & $\begin{array}{l}-0.8181^{* *} \\
(-2.09)\end{array}$ \\
\hline INST_PSENT & & $\begin{array}{l}0.3911^{* * *} \\
(2.84)\end{array}$ & $\begin{array}{l}0.3683^{* * *} \\
(2.88)\end{array}$ \\
\hline INST_OVER & & $\begin{array}{l}0.0506^{*} \\
(1.92)\end{array}$ & $\begin{array}{l}0.0039 \\
(0.15)\end{array}$ \\
\hline RETAIL_OVER & $\begin{array}{l}0.1753^{* * *} \\
(9.22)\end{array}$ & & $\begin{array}{l}0.1712^{* * *} \\
(9.09)\end{array}$ \\
\hline INST_BID & $\begin{array}{l}-0.5786^{* * *} \\
(-4.47)\end{array}$ & $\begin{array}{l}-0.5009^{* * *} \\
(-3.74)\end{array}$ & $\begin{array}{l}-0.5195^{* * *} \\
(-4.29)\end{array}$ \\
\hline LNNUM & $\begin{array}{l}0.2182^{* * *} \\
(5.60)\end{array}$ & $\begin{array}{l}0.2341^{* * *} \\
(4.77)\end{array}$ & $\begin{array}{l}0.2041^{* * *} \\
(4.51)\end{array}$ \\
\hline$R O A$ & $\begin{array}{l}-0.3633^{*} \\
(-1.72)\end{array}$ & $\begin{array}{l}-0.8303^{* * *} \\
(-3.65)\end{array}$ & $\begin{array}{l}-0.3290 \\
(-1.59)\end{array}$ \\
\hline LEV & $\begin{array}{l}-0.0200 \\
(-1.09)\end{array}$ & $\begin{array}{l}-0.0634^{* * *} \\
(-3.20)\end{array}$ & $\begin{array}{l}-0.0144 \\
(-0.75)\end{array}$ \\
\hline LNREV & $\begin{array}{l}-0.1246 \\
(-1.15)\end{array}$ & $\begin{array}{l}-0.1222 \\
(-1.03)\end{array}$ & $\begin{array}{l}-0.1490 \\
(-1.36)\end{array}$ \\
\hline FIXRAT & $\begin{array}{l}-0.0189 \\
(-0.26)\end{array}$ & $\begin{array}{l}-0.0154 \\
(-0.21)\end{array}$ & $\begin{array}{l}-0.0231 \\
(-0.32)\end{array}$ \\
\hline RANGE & $\begin{array}{l}0.3167 \\
(1.42)\end{array}$ & $\begin{array}{l}0.3860 \\
(1.59)\end{array}$ & $\begin{array}{l}0.2709 \\
(1.22)\end{array}$ \\
\hline LNLAG10 & $\begin{array}{l}-0.1081^{* * *} \\
(-3.50)\end{array}$ & $\begin{array}{l}-0.0008 \\
(-0.03)\end{array}$ & $\begin{array}{l}-0.1032^{* * *} \\
(-3.32)\end{array}$ \\
\hline INDACT & $\begin{array}{l}-0.0031 \\
(-0.21)\end{array}$ & $\begin{array}{l}-0.0045 \\
(-0.27)\end{array}$ & $\begin{array}{l}-0.0014 \\
(-0.10)\end{array}$ \\
\hline REPU & $\begin{array}{l}0.0094 \\
(0.38)\end{array}$ & $\begin{array}{l}0.0274 \\
(0.98)\end{array}$ & $\begin{array}{l}0.0201 \\
(0.80)\end{array}$ \\
\hline REFORM & $\begin{array}{l}-0.0300 \\
(-0.58)\end{array}$ & $\begin{array}{l}-0.0992^{*} \\
(-1.71)\end{array}$ & $\begin{array}{l}-0.0268 \\
(-0.52)\end{array}$ \\
\hline MAIN & $\begin{array}{l}0.0264 \\
(0.54)\end{array}$ & $\begin{array}{l}0.0012 \\
(0.02)\end{array}$ & $\begin{array}{l}0.0362 \\
(0.75)\end{array}$ \\
\hline Year & Yes & Yes & Yes \\
\hline Industry & Yes & Yes & Yes \\
\hline Adj. $R^{2}$ & 0.329 & 0.213 & 0.339 \\
\hline $\mathrm{F}$ & 9.3677 & 5.4812 & 9.0704 \\
\hline$N$ & 473 & 473 & 473 \\
\hline
\end{tabular}


Table 2. Investor sentiment and IPO long-term performance

\begin{tabular}{lll}
\hline & $(1)$ & $(2)$ \\
& LONGRET3 & LONGRET2 \\
\hline INTERCEPT & $2.9057^{* * *}$ & $1.8946^{* *}$ \\
& $(2.81)$ & $(2.25)$ \\
INST_PSENT & -0.3445 & -0.2759 \\
& $(-1.05)$ & $(-1.16)$ \\
INST_OVER & 0.0146 & 0.0220 \\
& $(0.23)$ & $(0.47)$ \\
RETAIL_OVER & $-0.1094^{* *}$ & $-0.0845^{* *}$ \\
& $(-2.49)$ & $(-2.37)$ \\
Control variables & Yes & Yes \\
Year & Yes & Yes \\
Industry & Yes & Yes \\
Adj. $R^{2}$ & 0.172 & 0.128 \\
$\mathrm{~F}$ & 4.6309 & 4.1123 \\
$N$ & 473 & 473 \\
\hline
\end{tabular}

